\title{
The Influence of the Extent of Color-Vision Deficiency on Shade- Matching Ability
}

\section{Utjecaj stupnja poremećaja kolornoga vida na sposobnost prepoznavanja boja}

\footnotetext{
${ }^{1}$ Prosthodontic Department, Faculty of Medicine, University of Ljubljana, Slovenia

Zavod za stomatološku protetiku Medicinskog fakulteta Sveučilišta u Ljubljani, Slovenija

2 Department of Ophthalmology, Faculty of Medicine, University of Ljubljana, Slovenia.

Zavod za oftalmologiju Medicinskog fakulteta Sveučilišta u Ljubljani, Slovenija

3 Prosthodontic Department, Faculty of Medicine, University of Ljubljana \& Prosthodontic Department, University Medical Centre Ljubljana, Slovenia

Zavod za stomatološku protetiku Medicinskog fakulteta Sveučilišta u Ljubljani i Zavod za stomatološku protetiku Sveučilišnog medicinskog centra Ljubljana, Slovenija
}

\section{Abstract}

Objective: To evaluate the influence of the extent of color-vision deficiency on visual shade-matching ability. Materials and methods: Six groups were investigated: the control group $(\mathrm{N}=68)$, the protan medium deficiency (PMED) group ( $N=5)$, the protan strong deficiency (PSTD) group $(\mathrm{N}=5)$, the deutan mild deficiency (DMID) group $(\mathrm{N}=5)$, the deutan medium deficiency (DMED) group $(\mathrm{N}=5)$ and the deutan strong deficiency (DSTD) group $(\mathrm{N}=8)$. The color vision of the participants was evaluated monocularly using the Hardy-Rand-Rittler (HRR) test and on an HMC Anomaloskop MR (Rayleigh test). The final exam on a Toothguide Training Box consisted of 15 lightness-chroma-hue tasks. The color difference $\left(\Delta \mathrm{E}^{*}{ }_{\mathrm{ab}}\right)$ and the shade-matching score $\left(\Sigma \Delta \mathrm{E}_{\mathrm{ab}}^{*}\right)$ were computed. The means and the standard deviations for the $\Sigma \Delta \mathrm{E}_{\mathrm{ab}}^{*}$ were calculated. An independent t-test was used for statistical analyses of the data and a comparison of means $(\alpha=.05)$ for protan groups and a one-way analysis of variance (ANOVA) and a post-hoc Bonferroni test $(\alpha=.05)$ for deutan groups. Results: The PSTD group had a mean $\Sigma \Delta \mathrm{E}^{*}$ ob $63.38 \pm 9.52$, which means their selections were significantly worse in comparison to the PMED group $\left(\Sigma \Delta \mathrm{E}^{*}{ }_{\mathrm{ab}}=47.62 \pm 9.88, p=0.033\right)$. The selections of the control group were significantly better in comparison to all groups with color-vision deficiency (control-PMED, $p=$ 0.031; control - PSTD, $p<0.0001$; control - DMED, $p<0.0001$; control - DSTD, $p<0.0001)$, except in comparison with DMID group $(p=0.082)$. The comparisons between deutan groups were not significantly different (DMID - DMED, $p=0.352$; DMID - DSTD, $p=0.323$; DMED - DSTD, $p=1.000$ ). Conclusion: Participants with strong protan color-vision deficiency are worse at shade matching than participants with medium protan color-vision deficiency.
Received: April 25, 2019

Accepted: July 18, 2019

Address for correspondence

Dr Boštjan Pohlen

Dental office Pohlen

Cesta talcev 010

1230 Domžale, Slovenia

Phone: +38641242600

pohlenb@yahoo.co.uk

\section{Key words}

Color Perception; Color Vision Defects; Matched-Pair Analysis

\section{Introduction}

Shade matching is present in daily restorative and esthetic dentistry. Shade matching is performed by using visual and/ or instrumental methods. Although many instruments have been developed for shade matching, it has been done most frequently using the visual method. The visual method is known as shade matching and is performed using dental shade guides. A tooth or restoration is compared with color standards, usually in a tooth-shape form, made of ceramics, acrylic or composite. The factors that influence the shade matching are more important for the visual method (1). Congenital color-vision deficiencies affect visual shade matching $(2,3)$. Congenital color-vision deficiencies can be divided in protan red-green deficiency (predominantly red axis affected) and deutan red-green deficiency (predominantly green axis affect-

\section{Uvod}

Određivanje boje svakodnevni je zadatak u restaurativnoj i estetskoj dentalnoj medicini. Boja se određuje vizualnim i/ ili instrumentalnim metodama. Iako postoje mnogi instrumenti za određivanje boje, najčešće se ipak primjenjuje vizualna metoda. Vizualna metoda određivanja boje obavlja se s pomoću ključa boja. Zub ili restauracija uspoređuju se sa standardima boja, obično u obliku zuba izrađenih od keramike, akrilata ili kompozita. Čimbenici koji utječu na određivanje boje važniji su za vizualnu metodu (1). Kongenitalni poremećaji kolornoga vida utječu na vizualno određivanje boje $(2,3)$. Mogu se podijeliti na protanopiju (pretežno smanjena osjetljivost za crvenu) i deuteranopiju (pretežno smanjena osjetljivost za zelenu). Hardy-Rand-Rittlerov (HRR) test (4) identificira poremećaje kolornoga vida u crveno-zelenom 
ed). Hardy-Rand-Rittler (HRR) test (4) identifies color-vision red-green and blue-yellow deficiencies and can differentiate the extent of the deficiency in mild, medium and strong, separately for red-green and blue-yellow color-vision deficiencies. To the present authors' knowledge, the influence of the extent of the participant's color-vision deficiency measured with the HRR test on the visual shade-matching ability on Toothguide Training Box (5) (TTB) or VITA 3D-Master shade guide has yet not been published. The purpose of this study was to evaluate the influence of the extent of color-vision deficiency on the visual shade-matching ability. The null hypothesis was that shade-matching score, $\Sigma \Delta \mathrm{E}_{\mathrm{ab}}^{*}$, of participants with strong color-vision deficiencies would not differ from the score of participants with medium or mild color-vision deficiencies. The second null hypothesis was that shade-matching score, $\Sigma \Delta \mathrm{E}_{\mathrm{ab}}^{*}$, of the control group would not differ from the score of all other groups with color-vision deficiencies.

\section{Materials and methods}

The work has been approved by the appropriate Ethics Committee related to the institution in which it was performed. Informed consent was obtained for experimentation with human subjects. The study was presented in broader extent in a previous article by Pohlen et al (3). The color vision of the participants was evaluated monocularly using the HRR test. The test is a color-vision-deficiency test with 24 pseudoisochromatic plates in a book. The participants with a color-vision deficiency found on the HRR test were also tested on an HMC Anomaloskop MR (Rayleigh test (OCULUS Optikgerate)) to confirm the diagnosis for red-green color-vision deficiency. Six groups were formed based on the results obtained on the HRR test: the control group (without color-vision deficiencies) $(\mathrm{N}=68)$, the protan medium deficiency (PMED) group $(\mathrm{N}=5)$, the protan strong deficiency (PSTD) group $(\mathrm{N}=5)$, the deutan mild deficiency (DMID) group $(\mathrm{N}=5)$, the deutan medium deficiency (DMED) group $(\mathrm{N}=5)$ and the deutan strong deficiency (DSTD) group $(\mathrm{N}=8)$. One color-vision-deficient participant (diagnosis based on the Rayleigh test on the anomaloscope) was excluded from the study, because no color-vision deficiencies were found on the HRR test.

The HRR test differentiates color vision into normal if correct responses were given to all six screening plates. Protan red-green deficiency (predominantly red axis affected) was classified if the total number of checks in the protan column was greater than in the deutan column. Deutan red-green deficiency (predominantly green axis affected) was classified if the total number of checks in the deutan column was greater than in the protan column. The extent of all the defects could be mild, medium or strong. The last group of plates in which errors occur gave the extent of the participant's colorvision deficiency (4).

Color-vision deficient participants were also tested monocularly on an HMC Anomaloskop MR (Rayleigh test). An anomaloscope is an optical device designed to test color vision by matching a yellow light which may be varied in intensity with a combination of red and green lights of constant intensity. i plavo-žutom spektru i može ih razlikovati prema stupnju kao blage, srednje i jake. Prema dosadašnjim spoznajama autora, nije objavljeno istraživanje o utjecaju stupnja poremećaja kolornoga vida sudionika izmjereno HRR testom na sposobnost vizualnog određivanja boje u Toothguide Training Boxu (5) (TTB) ili ključu boja VITA 3D-Master. Svrha ovog istraživanja bila je procijeniti utjecaj stupnja poremećaja kolornoga vida na sposobnost vizualnog određivanja boje. Nulta hipoteza bila je da se ocjena podudaranja boje $-\Sigma \Delta \mathrm{E}^{*} \mathrm{ab}$, sudionika s jakim poremećajem kolornoga vida ne bi trebala razlikovati od rezultata sudionika sa srednjim ili blagim poremećajem. Druga nulta hipoteza glasila je da se rezultat podudaranja boje $-\Sigma \Delta \mathrm{E}^{*} \mathrm{ab}$, u kontrolnoj skupini ne razlikuje od rezultata svih ostalih skupina s poremećajem kolornoga vida.

\section{Materijali i metode}

Istraživanje je odobrilo Etičko povjerenstvo institucije u kojoj je provedeno. Dobivena je suglasnost za istraživanje na ljudima. Istraživanje je opširnije predstavljeno u ranijem radu Pohlena i suradnika (3). Kolorni vid sudionika ocijenjen je monokularno primjenom HRR testa. Riječ je o testu poremećaja kolornoga vida s 24 pseudoizokromatske ploče u knjizi. Sudionici s poremećajem kolornoga vida koji su otkriveni HRR testom također su testirani na HMC anomaloskopu MR (Rayleighev test, OCULUS Optikgerate) kako bi potvrdili dijagnozu za crveno-zeleni daltonizam. Na temelju rezultata dobivenih HRR testom formirano je šest skupina: kontrolna skupina (bez poremećaja kolornoga vida) $(\mathrm{N}=68)$, skupina sa srednjom protanopijom (PMED) $(\mathrm{N}=5)$, skupina $s$ jakom protanopijom (PSTD) $(\mathrm{N}=5)$, skupina $s$ blagom deuteranopijom (DMID) $(\mathrm{N}=5)$, skupina sa srednjom deuteranopijom (DMED) $(\mathrm{N}=5)$ i skupina s jakom deuteranopijom (DSTD) $(\mathrm{N}=8)$. Jedan sudionik s poremećajem kolornoga vida (dijagnoza na temelju Rayleighova testa na anomaloskopu) isključen je iz istraživanja jer na HRR testu nisu utvrđeni nedostatci.

HRR test diferencira kolorni vid na normalan ako su na svih šest ploča za provjeru dobiveni pravilni odgovori. Crveno-zelena protanopija (pogođena pretežno crvena os) prisutna je ako je ukupni broj pogodaka u protanskom stupcu bio veći negoli u deutanskom. Crveno-zelena deuteranopija (pretežno zelena os) prisutna je ako je ukupni broj pogodaka u deutanskom stupcu bio veći negoli u protanskom. Stupanj svih poremećaja može biti blag, srednji ili jak. Posljednja skupina ploča u kojima se pojavljuju pogreške daje informaciju o poremećaju kolornoga vida kod sudionika (4).

Sudionici s poremećajem kolornoga vida također su testirani monokularno na HMC anomaloskopu MR (Rayleighov test). Anomaloskop je optički uređaj za ispitivanje kolornoga vida i spaja žutu svjetlost različitog intenziteta s kombinacijom crvene i zelene svjetlosti stalnog intenziteta.

Protokol s Toothguide Training Boxom (5) bio je jednak kao u istraživanju Pohlena i suradnika (3). Završno testiranje bilo je binokularno i sastojalo se od 15 zadataka za odredivanje svjetline - zasićenja - tona. Ti rezultati za podudara- 
The protocol on the Toothguide Training Box (5) was the same as in Pohlen et al (3). The final exam was tested binocularly and it consisted of 15 lightness-chroma-hue tasks. These shade-matching results were recorded on a laptop computer connected to the TTB and were subsequently processed. The color difference $\left(\Delta \mathrm{E}_{\mathrm{ab}}^{*}\right)$ between the task tab and the selected tab was computed as follows:

$$
\Delta \mathrm{E}_{\mathrm{ab}}^{*}=\left(\left(\Delta \mathrm{L}^{*}\right)^{2}+\left(\Delta \mathrm{a}^{*}\right)^{2}+\left(\Delta \mathrm{b}^{*}\right)^{2}\right)^{1 / 2}
$$

where $\Delta \mathrm{L}^{*}, \Delta \mathrm{a}^{*}$ and $\Delta \mathrm{b}^{*}$ denote the differences in the lightness, chroma and hue coordinates.

The $\mathrm{L}^{*}, \mathrm{a}^{*}$ and $\mathrm{b}^{*}$ values of all 26 shade tabs were obtained from measuring three completely new shade guides with a spectrophotometer VITA Easyshade Advance. Each tab was measured three times under color-corrected light (Dialite Color, Eickhorst, Germany) with a color-correlated temperature of $5500 \mathrm{~K}, 1500$ lux and $92 \mathrm{CRI}$. The average of all nine measurements was taken as the $L^{*}, a^{*}$ and $b^{*}$ values of each of the 26 shade tabs, as in Pohlen et al (6) (Table 1).

The shade-matching score, $\Sigma \Delta \mathrm{E}_{\mathrm{ab}}^{*}$, for each participant was computed as the sum of the color differences $\left(\Delta \mathrm{E}^{*}{ }^{2}\right)$ between all the task tabs and the selected tabs. The lower $\Sigma \Delta \mathrm{E}_{\mathrm{ab}}^{*}$ scores corresponded to better shade-matching results and vice versa. For a set of 15 exact matches this score would be zero. The means and the standard deviations for $\Sigma \Delta \mathrm{E}_{\mathrm{ab}}^{*}$ were calculated.

An independent t-test was used for statistical analyses of the data and a comparison of means $(\alpha=.05)$ for protan groups and a one-way analysis of variance (ANOVA) and a post-hoc Bonferroni test $(\alpha=.05)$ for deutan groups. A one- nje boje zabilježeni su na prijenosnom računalu spojenom na TTB i naknadno su obrađeni. Razlika u boji ( $\left.\Delta \mathrm{E}^{*} \mathrm{ab}\right)$ između zadanog uzorka i odabrane boje izračunata je sljedećom jednadžbom:

$$
\Delta \mathrm{E}^{*} \mathrm{ab}=\left(\left(\Delta \mathrm{L}^{*}\right) 2+\left(\Delta \mathrm{a}^{*}\right) 2+\left(\Delta \mathrm{b}^{*}\right) 2\right)^{1 / 2},
$$

pri čemu $\Delta \mathrm{L}^{*}, \Delta \mathrm{a}^{*} \mathrm{i} \Delta \mathrm{b}^{*}$ označavaju razlike u koordinati svjetline, zasićenja $\mathrm{i}$ tona.

Vrijednosti L*, a* i b* svih 26 uzoraka boja dobivene su mjerenjem triju potpuno novih ključeva boja spektrofotometrom VITA Easyshade Advance. Svaki uzorak izmjeren je tri puta pod korigiranim svjetlom (Dialite Color, Eickhorst, Njemačka) s temperaturom od $5500 \mathrm{~K}, 1500$ luksa i 92 CRI. Prosjek svih devet mjerenja uzet je kao vrijednost $\mathrm{L}^{*}, \mathrm{a}^{*} \mathrm{i} \mathrm{b}^{*}$ za svaki od 26 uzoraka, kao u istraživanju Pohlena i suradnika (6) (tablica 1.).

Ocjena podudaranja boje $-\Sigma \Delta \mathrm{E}^{*}$ ab, za svakog sudionika izračunata je kao zbroj razlika u boji ( $\Delta \mathrm{E}^{*}$ ab) između svih zadanih i odabranih uzoraka. Niži rezultati za $\Sigma \Delta \mathrm{E}^{*}$ ab odgovarali su boljim rezultatima podudaranja boje i obrnuto. Za set od 15 točnih podudaranja taj rezultat bio bi jednak nuli. Izračunati su prosjek i standardna devijacija za $\Sigma \Delta \mathrm{E}^{*}$ ab.

$\mathrm{Za}$ statističke analize podataka upotrijebljeni su neovisni t-test i usporedba sredina $(\alpha=0,05)$ za skupine s protanopijom te jednosmjerna analiza varijance (ANOVA) i post-hoc Bonferronijev test $(\alpha=0,05)$ za skupine $s$ deuteranopijom. Za usporedbu svih skupina s kontrolnom skupinom korišteni su jednosmjerna analiza varijance (ANOVA) i Bonferronijev post-hoc test $(\alpha=0,05)$. Analiza podataka obavljena je u programu SPSS 22,0 za Windowse (IBM).
Table $1 \quad L^{\star}$, $a^{\star}$ and $b^{\star}$ values of the 26 shade tabs from the VITA 3D-Master measured with the VITA Easyshade Advance spectrophotometer.

Tablica 1. L*, a* i b* vrijednosti 26 uzoraka VITA 3D-Mastera mjerenih

\begin{tabular}{|c|c|c|c|}
\hline & $\mathrm{L}^{*}$ & $a^{*}$ & $\mathbf{b}^{*}$ \\
\hline $1 \mathrm{M} 1$ & 85.06 & -1.91 & 11.43 \\
\hline $1 \mathrm{M} 2$ & 85.46 & -1.86 & 17.59 \\
\hline $2 \mathrm{M} 1$ & 81.24 & -0.76 & 12.96 \\
\hline 2L1.5 & 80.97 & -1.48 & 16.21 \\
\hline 2L2.5 & 81.22 & -1.26 & 21.61 \\
\hline $2 \mathrm{M} 2$ & 81.58 & -0.38 & 18.33 \\
\hline 2R1.5 & 80.94 & -0.06 & 15.34 \\
\hline 2R2.5 & 80.68 & 0.09 & 21.2 \\
\hline $2 \mathrm{M} 3$ & 81.21 & -0.44 & 24.04 \\
\hline $3 \mathrm{M} 1$ & 75.77 & 0.26 & 13.94 \\
\hline 3L1.5 & 74.29 & -0.1 & 17.88 \\
\hline 3L2.5 & 75.26 & 0.52 & 23.77 \\
\hline $3 \mathrm{M} 2$ & 76.79 & 1.07 & 21.07 \\
\hline 3R1.5 & 75.01 & 1.17 & 16.06 \\
\hline 3R2.5 & 75.21 & 1.63 & 22.84 \\
\hline $3 \mathrm{M} 3$ & 76.69 & 1.38 & 26.32 \\
\hline $4 \mathrm{M} 1$ & 70.62 & 1.57 & 15.34 \\
\hline 4L1.5 & 71.2 & 1.27 & 19.64 \\
\hline 4L2.5 & 70.91 & 2.1 & 25.7 \\
\hline $4 \mathrm{M} 2$ & 71.57 & 2.48 & 21.97 \\
\hline 4R1.5 & 71.22 & 2.83 & 18.93 \\
\hline 4R2.5 & 70.99 & 3.46 & 24.7 \\
\hline $4 \mathrm{M} 3$ & 71.47 & 3.24 & 29.3 \\
\hline $5 \mathrm{M} 1$ & 65.99 & 2.52 & 16.87 \\
\hline $5 \mathrm{M} 2$ & 67.16 & 4.2 & 24.56 \\
\hline $5 \mathrm{M} 3$ & 68.06 & 5.54 & 33.3 \\
\hline
\end{tabular}
spektrofotometrom VITA Easyshade Advance 
way analysis of variance (ANOVA) and a post-hoc Bonferroni test $(\alpha=.05)$ was also used for comparison of all groups with the control group. The data analysis was performed using SPSS 22.0 for Windows (IBM).

\section{Results}

The PSTD group had a mean $\Sigma \Delta \mathrm{E}_{\text {ab }}^{*}$ of $63.38 \pm 9.52$, which means their selections were significantly worse in comparison to the PMED group $\left(\Sigma \Delta \mathrm{E}_{\mathrm{ab}}^{*}=47.62 \pm 9.88, p=\right.$ 0.033 , Tables 2, 3, Figure 1). The selections of the control group were significantly better in comparison to all groups with color-vision deficiency (control - PMED, $p=0.031$; control - PSTD, $p<0.0001$; control - DMED, $p<0.0001$; control - DSTD, $p<0.0001)$, except in comparison with DMID group $(p=0.082)$. The comparisons between deutan groups were not significantly different (DMID - DMED, $p$ $=0.352$; DMID - DSTD,$p=0.323$; DMED - DSTD,$p$ $=1.000)$ (Tables 2-4). The $\Sigma \Delta \mathrm{E}_{\mathrm{ab}}^{*}$ of the final exam for all groups are presented in Table 2 .

\section{Rezultati}

Skupina s PSTD-om imala je prosječnu vrijednost za $\Sigma \Delta \mathrm{E}^{*}$ ab od $63,38 \pm 9,52$, što znači da su njihovi odabiri bili značajno lošiji u usporedbi sa skupinom $s$ PMED-om $\left(\Sigma \Delta \mathrm{E}^{*} \mathrm{ab}=47,62 \pm 9,88, \mathrm{p}=0,033\right.$, tablice 2. i 3., slika 1.). Odabiri kontrolne skupine bili su značajno bolji u usporedbi sa svim skupinama s poremećajem kolornoga vida (kontrola - PMED, $\mathrm{p}=0,031$; kontrola - PSTD, $\mathrm{p}<0,0001$; kontrola - DMED, $\mathrm{p}<0,0001$; kontrola - DSTD, $\mathrm{p}<0,0001)$, osim u usporedbi sa skupinom s DMID-om ( $\mathrm{p}=0,082)$. Usporedbe između skupina $s$ deuteranopijom nisu se značajno razlikovale (DMID - DMED, $\mathrm{p}=0,352$; DMID - DSTD, $\mathrm{p}=0,323$; DMED - DSTD, $\mathrm{p}=1,000)$ (tablice 2. do 4.). $\Sigma \Delta \mathrm{E}^{*}$ ab završnoga testa za sve skupine prikazan je u tablici 2.

Table 2 The results of the final exam on the TTB $\left(\Sigma \Delta \mathrm{E}^{\star}{ }_{\mathrm{ab}} \pm\right.$ Std. Deviation) and test statistics (independent test for protan groups and a oneway analysis of variance (ANOVA) for deutan groups) for $\Sigma \Delta \mathrm{E}^{*}{ }_{\mathrm{ab}}$.

Tablica 2. Rezultati završnog testa na TTB-u $\left(\Sigma \Delta \mathrm{E}^{*}{ }_{\text {ab }} \pm\right.$ std. devijacija) i statističkih testova (nezavisni t-test za skupine s protanopijom $\mathrm{i}$ jednosmjerna analiza varijance (ANOVA) za skupine $s$ duteranopijom) za $\Sigma \Delta \mathrm{E}^{\star}{ }_{a b}$.

\begin{tabular}{|c|c|c|c|c|c|c|c|}
\hline & & $\mathbf{n}$ & Mean $\cdot$ Sredina & SD & t & df & $p$ \\
\hline Control $\bullet$ Kontrola & & 68 & 31.57 & 13.50 & & & \\
\hline \multirow{5}{*}{ Protan $\bullet$ Protanopija } & Mild・Blaga (PMID) & 0 & 0 & 0 & & & \\
\hline & Medium • Srednja (PMED) & 5 & 47.62 & 9.88 & -2.569 & 8 & 0.033 \\
\hline & Strong • Jaka (PSTD) & 5 & 63.38 & 9.52 & & & \\
\hline & Sum $・$ Ukupno & 10 & 55.50 & 12.36 & & & \\
\hline & & & & & F & df & $p$ \\
\hline \multirow{4}{*}{ Deutan $\bullet$ Deuteranopija } & Mild • Blaga (DMID) & 5 & 47.92 & 11.93 & & & \\
\hline & Medium • Srednja (DMED) & 5 & 64.73 & 13.20 & 1.831 & 2 & 0.194 \\
\hline & Strong • Jaka (DSTD) & 8 & 63.52 & 19.16 & & & \\
\hline & Sum $・$ Ukupno & 18 & 59.52 & 16.76 & & & \\
\hline
\end{tabular}

Table 3 A one-way analysis of variance (ANOVA) for the control and protan groups.

Tablica 3. Jednosmjerna analiza varijance (ANOVA) za kontrolnu

skupinu i skupinu s protanopijom

\begin{tabular}{|c|c|c|}
\hline $\mathbf{F}$ & $\mathbf{d f}$ & $\boldsymbol{p}$ \\
16.224 & 2 & $<0.0001$ \\
\hline
\end{tabular}

Table 4 A one-way analysis of variance (ANOVA) for the control and deutan groups.

Tablica 4. Jednosmjerna analiza varijance (ANOVA) za kontrolnu skupinu i skupinu s deuteranopijom

\begin{tabular}{|c|c|c|}
\hline $\mathbf{F}$ & $\mathbf{d f}$ & $\boldsymbol{p}$ \\
20.521 & 3 & $<0.0001$ \\
\hline
\end{tabular}

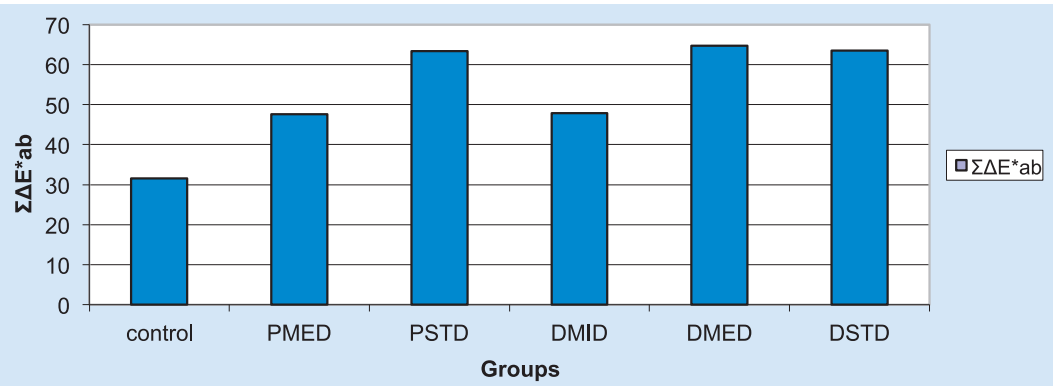

Figure $1 \Sigma \Delta \mathrm{E}^{*}$ for the final exam on the TTB.

Slika 1. $\Sigma \Delta \mathrm{E}^{\mathrm{ab}}$ za završni test na TTB-u 


\section{Discussion}

Approximately $8 \%$ of males have congenital color-vision deficiencies (7-9) in comparison with $0.5 \%$ females $(7,9)$. Research on the effect of color-vision deficiencies on visual shade matching is rare, because congenital color-vision deficiencies are rare and are an "immensely well-kept secret" (10). Secondly, research is mostly not able to discriminate different color-vision deficiencies (i.e. anomalous trichromats- protanomalia, deuteranomalia, tritanomalia from dichromats (more severe deficiency- protanopia, deuteranopia, and tritanopia)). In addition, it is not able to evaluate the extent of the subject's color-vision deficiency measured with the HRR test (i.e., mild, medium, strong) and its influence on visual shade-matching ability. Classifying by severity of the red-green color-vision deficiency is more useful for predicting the effect on performance (11). Spalding (11) reported that subjects (medical doctors) with moderate and severe deficiencies had more difficulties compared with the results of those with mild deficiencies. The present study was able to evaluate the extent of the subject's color-vision deficiency measured by the HRR test and differentiate it in mild, medium or strong deficiency, separately for protan and deutan red-green deficiency. Five color-vision deficient groups were formed: the protan medium deficiency (PMED) group $(\mathrm{N}=$ $5)$, the protan strong deficiency (PSTD) group $(\mathrm{N}=5)$, the deutan mild deficiency (DMID) group $(\mathrm{N}=5)$, the deutan medium deficiency (DMED) group $(\mathrm{N}=5)$ and the deutan strong deficiency (DSTD) group $(\mathrm{N}=8)$. In addition, it was able to evaluate the influence of the extent of the subject's color-vision deficiency on visual shade-matching ability (Tables 2-4). The results of the present study showed that PSTD group $\left(\Sigma \Delta \mathrm{E}_{\mathrm{ab}}^{*}=63.38 \pm 9.52\right)$ was significantly worse in shade matching than PMED $\left(\Sigma \Delta \mathrm{E}_{\mathrm{ab}}^{*}=47.62 \pm 9.88, p\right.$ $=0.033)$. To the present author' knowledge, the information that a greater protan color-vision deficiency extent has more influence on visual shade-matching ability on Toothguide Training Box (TTB) or VITA 3D-Master shade guide has yet not been published before. On the contrary to protan color-vision deficiency, there were not significant differences between deutan groups. This is the reason why the first null hypothesis can be rejected only for protan (predominantly red axis affected) color-vision deficiency.

The selections of the control group were significantly better in comparison to all groups with color-vision deficiency, except in comparison with mild deutan red-green color-vision deficiency group. The piece of information that colorvision deficiency affects shade matching is not new. It is in accordance with many previous studies, $(2,3,12-15)$ and it is in fact "common sense". This is the reason why the second null hypothesis can be rejected for all protan and deutan color-vision deficiency groups, except for DMID group. Further investigations with more participants with different extents of color-vision deficiencies are needed in future.

\section{Conclusion}

The extent of the participant's color-vision deficiency measured with the HRR test partially affects the visual shade-

\section{Rasprava}

Otprilike $8 \%$ muškaraca ima kongenitalni poremećaj kolornoga vida $(7-9)$ u usporedbi s $0,5 \%$ žena $(7,9)$. Istraživanja utjecaja poremećaja kolornoga vida na vizualno određivanje boja rijetka su jer su kongenitalni poremećaji kolornoga vida rijetki i neizmjerno su dobro čuvana tajna (10). Isto tako, u istraživanjima se uglavnom ne mogu razlikovati različiti poremećaji kolornoga vida (tj. trikromatske anomalije protanomalija, deuteranomalija, tritanomalija od dikromatskih anomalija - protanopije, deuteranopije i tritanopije). Uz to, ne mogu se procijeniti opseg subjektivnog nedostatka kolornoga vida mjeren HRR testom (tj. blagi, srednji, jaki) i njegov utjecaj na sposobnost vizualnog određivanja boje. Razvrstavanje prema težini poremećaja kolornoga vida u crveno-zelenom spektru korisnije je za predviđanje sposobnosti razlikovanja boja (11). Spalding (11) je istaknuo da su ispitanici (liječnici) s umjerenim i teškim poremećajem kolornoga vida imali više poteškoća u usporedbi s rezultatima onih s blagim poremećajem. U ovom su istraživanju autori uspjeli procijeniti opseg poremećaja kolornoga vida mjerenjem HRR testom i podijeliti ga na blagu, srednju ili jaku protanopiju i deuteranopiju. Formirano je pet skupina s poremećajem kolornoga vida: skupina sa srednjom protanopijom (PMED) $(\mathrm{N}=5)$, skupina $s$ jakom protanopijom (PSTD) $(\mathrm{N}=5)$, skupina s blagom deuteranopijom (DMID) (N = 5), skupina sa srednjom deuteranopijom (DMED) $(\mathrm{N}=5)$ i skupina $s$ jakom deuteranopijom (DSTD) $(\mathrm{N}=8)$. Uz to, mogao se procijeniti utjecaj stupnja poremećaja kolornoga vida subjekta na sposobnost određivanja boje (tablice 2. do 4.). Rezultati ovog istraživanja pokazali su da je skupina s PSTDom $\left(\Sigma \Delta \mathrm{E}^{*} \mathrm{ab}=63,38 \pm 9,52\right)$ bila značajno lošija u određivanju boje u odnosu na onu s PMED-om $\left(\Sigma \Delta \mathrm{E}^{*} \mathrm{ab}=47,62 \pm\right.$ 9,88, $\mathrm{p}=0,033)$. Prema spoznajama autora, nema objavljenih podataka o tome kako stupanj poremećaja kolornoga vida utječe na sposobnost određivanja boje u Toothguide Training Boxu (TTB) ili ključu boja VITA 3D-Master. Za razliku od protanopije, nije bilo statistički značajnih razlika između skupina s deuteranopijom. To je razlog zašto se može odbaciti prva nulta hipoteza.

Odabiri kontrolne skupine bili su značajno bolji u usporedbi sa svim skupinama s poremećajima kolornoga vida, osim u usporedbi s blagom deuteranopijom. Podatak da poremećaj kolornoga vida utječe na sposobnost određivanja boje nije nov. To je u skladu s mnogim dosadašnjim istraživanjima $(2,3,12-15)$ i zapravo je zdravorazumski. To je razlog zbog kojeg se druga nulta hipoteza može odbaciti za sve skupine, osim za onu s DMID-om. U budućnosti su potrebna daljnja istraživanja $s$ više sudionika $s$ različito izraženim poremećajem kolornoga vida.

\section{Zaključak}

Opseg poremećaja kolornoga vida mjeren HRR testom djelomično utječe na sposobnost vizualnog određivanja bo- 
matching ability. Participants with strong protan red-green color-vision deficiency are worse in shade matching than participants with medium protan red-green deficiency. The selections of the control group were significantly better in comparison to all groups with color-vision deficiency, except in comparison with the mild deutan red-green color-vision deficiency group.

\section{Conflict of interests}

All authors disclose any financial and personal relationships with other people or organizations that could inappropriately influence (bias) our work. je. Sudionici s jakom protanopijom lošije su određivali boje u odnosu prema onima sa srednjom protanopijom. Odabiri kontrolne skupine bili su značajno bolji u usporedbi sa svim skupinama s poremećajima kolornoga vida, osim u usporedbi sa skupinom $s$ blagom deuteranopijom.

\section{Sukob interesa}

Svi autori isključuju bilo kakve financijske ili osobne odnose s ljudima ili organizacijama koji bi mogli utjecati na nepristranost u ovom radu.

\section{Sažetak}

Cilj: Željelo se procijeniti utjecaj stupnja oštećenja kolornoga vida na sposobnost vizualnog određivanja boje. Materijali i metode: Ispitano je šest skupina: kontrolna skupina $(\mathrm{N}=68)$, skupina sa srednjom protanopijom (PMED) $(\mathrm{N}=5)$, skupina s jakom protanopijom (PSTD) $(\mathrm{N}=5)$, skupina s blagom deuteranopijom (DMID) $(N=5)$, skupina sa srednjom deuteranopijom (DMED) $(N=5)$ i skupina $\mathrm{s}$ jakom deuteranopijom (DSTD) $(\mathrm{N}=8)$. Kolorni vid sudionika ocijenjen je monokularno primjenom Hardy-Rand-Rittlerova testa (HRR) i na HMC anomaloskopu MR (Rayleighev test). Završni test sastojao se od 15 zadataka za određivanja svjetline - zasićenja - nijanse s pomoću Toothguide Training Boxa. Izračunata je razlika u boji $\left(\Delta E^{\star} a b\right)$ i ocjena je podudaranja boja ( $\left.\Sigma \Delta E^{\star} a b\right)$. Izračunati su prosjeci i standardne devijacije za $\Sigma \Delta \mathrm{E}^{\star}$ ab. Za statističku analizu podataka upotrijebljen je neovisni t-test i usporedba sredina $(\alpha=0,05)$ za skupine s protanopijom te jednosmjerna analiza varijance (ANOVA) i Bonferronijev post-hoc test $(\alpha=, 05)$ za skupine s deuteranopijom. Rezultati: Skupina s PSTD-om imala je prosječnu vrijednost za $\Sigma \Delta E^{\star}$ ab od $63,38 \pm 9,52$, što znači da su odabiri ispitanika bili značajno lošiji u usporedbi sa skupinom s PMED-om $\left(\Sigma \Delta E^{\star} a b=47,62 \pm 9,88, p=0,033\right)$. Odabiri u kontrolnoj skupini bili su značajno bolji u usporedbi sa svim skupinama s poremećajem kolornoga vida (kontrola - PMED, $p=0,031$; kontrola - PSTD, $p<0,0001$; kontrola - DMED, $p<0,0001$; kontrola DSTD, $p<0,0001)$, osim u usporedbi sa skupinom s DMID-om $(p=0,082)$. Usporedbe između skupina s deuteranopijom nisu se značajno razlikovale (DMID - DMED, $p=0,352$; DMID - DSTD, $p=0,323$; DMED - DSTD, $p=1,000)$. Zaključak: Sudionici s jakom protanopijom lošije su sparivali uzorke boja u odnosu prema sudionicima sa srednjom protanopijom.
Zaprimljen: 25. travnja 2019.

Prihvaćen: 18. srpnja 2019.

Adresa za dopisivanje

Dr. Boštjan Pohlen

Stomatološka ordinacija Pohlen

Cesta talcev 010

1230 Domžale, Slovenija

tel: +38641242600

pohlenb@yahoo.co.uk

Ključne riječi

opažanje boja; nedostatak viđenja boja; analiza parnih uzoraka

\section{References}

1. Horn DJ, Bulan-Brady J, Hicks ML. Sphere spectrophotometer versus human evaluation of tooth shade. J Endod. 1998 Dec;24(12):786-90.

2. Gokce HS, Ceyhan D, Piskin B, Gokce SM, Arisan V. Shade matching performance of normal and color vision-deficient dental professionals with standard daylight and tungsten illuminants. J Prosthet Dent. 2010 Mar;103(3):139-47.

3. Pohlen B, Hawlina M, Tekavcic Pompe M, Kopac I. Do Type 1 Diabetes Mellitus and Color-Vision Deficiencies Influence ShadeMatching Ability? Int J Prosthodont. 2018 May/Jun;31(3):239247.

4. Neitz, J; Bailey, JE - editors. Pseudoisochromatic plates. 4th ed. Boca Raton: Richmond Products; 2002.

5. Kroszewsky K, Jakstat HA. Learning an teaching color-taking. Deut Zahnärztl Z 2004;59:593-5.

6. Pohlen B, Hawlina M, Šober K, Kopač I. Tooth Shade-Matching Ability Between Groups of Students with Different Color Knowledge. Int J Prosthodont. 2016 Sep-Oct;29(5):487-92.

7. Saleski CG. Color, light, and shade matching. J Prosthet Dent 1972;27:263-8.
8. Preston, JD; Bergen, SF - editors. Color science and dental art. 1 st ed. St. Louis: CV Mosby Co; 1980.

9. Chamberlain, G); Chamberlain, DG - editors. Color-its measurement. Computation and application. 1 st ed. London: Heyden; 1980.

10. Bradley N. Colour blindness: notes on its development and clinical significance. Int J Psychoanal 1970;51:59-70.

11. Spalding JAB. Colour vision deficiency in the medical profession. B Br J Gen Pract. 1999 Jun;49(443):469-75.

12. Davison SP, Myslinski NR. Shade selection by color vision defective dental personnel. J Prosthet Dent. 1990 Jan;63(1):97-101.

13. Paravina RD, O’Neill PN, Swift Jr. EJ, Nathanson D, Goodacre CJ. Teaching of color in predoctoral and postdoctoral dental education in 2009. J Dent. 2010;38 Suppl 2:e34-40.

14. Brewer JD, Wee A, Seghi R. Advances in color matching. Dent Clin North Am. 2004 Apr;48(2):v, 341-58.

15. Borbely J, Varsanyi B, Fejerdy P, Hermann P, Jakstat H. Toothguide Trainer tests with color vision deficiency simulation monitor. J Dent. 2010;38s:e41-e9. 